\title{
Komplex kezelési eljárás kidolgozása háztartási mosóvizek újrahasznosításához
}

\section{Development of a Complex Treatment Process for Recycling Household Laundry Water}

\author{
Kelemen Orsolya, ${ }^{1}$ Bodnár Ildikó, ${ }^{2}$ Izbékiné Szabolcsik Andrea ${ }^{3}$ \\ Debreceni Egyetem, Müszaki Kar, Környezetmérnöki Tanszék, Debrecen, Magyarország \\ ${ }^{1}$ kelemen727@gmail.com \\ 22bodnari@eng.unideb.hu \\ ${ }^{3}$ szabolcsikandi@eng.unideb.hu
}

\begin{abstract}
The goal of our research is to study the treatment possibilities of the laundry water fraction of domestic greywater as an alternative water source, as well as to apply a complex treatment method with witch we obtain purified greywater that can be used during household tasks that do not require drinking water. By optimizing each treatment step, we determined a complex process with the following steps: coagulation-quartz sand filtration-oxidation. We also investigated the usability of purified greywater for irrigation by performing a standardized seedling test and determining the SAR factor. In conclusion, based on the measured and analysed water analytical parameters, we have successfully applied an appropriate complex treatment method, using optimal amounts of chemicals, which according to international recommendations can be potentially reused at household level, and can also be used for irrigation purposes.
\end{abstract}

Keywords: greywater, laundry water, treatment, reuse, sustainability.

\section{Összefoglalás}

Kutatásunk célja a mosásból származó szürkevízfrakció mint alternatív vízforrás kezelési lehetőségeinek tanulmányozása, valamint egy olyan komplex kezelési metódus alkalmazása, mellyel háztartási szinten ivóvizet nem igénylő feladatok során felhasználható tisztított szürkevizet kapunk. Az egyes kezelési lépések optimálásával összeállítottunk egy komplex eljárást melynek lépései: koagulálás-kvarchomokon történő szürés-oxidálás. Vizsgáltuk továbbá a tisztított szürkevíz öntözési célú felhasználhatóságát szabványosított csíranövényteszt elvégzésével és a SAR-tényező meghatározásával. Összességében elmondható, hogy a mért és elemzett vízanalitikai paraméterek alapján sikeresen alkalmaztunk egy megfelelő komplex kezelési metódust, optimális vegyszermennyiségek használatával, mely a nemzetközi ajánlások alapján háztartási szinten potenciálisan újrafelhasználható, valamint a csíranövényteszt alapján öntözési célokra is alkalmazható.

Kulcsszavak: szürkevíz, mosóvíz, kezelés, újrahasználat, fenntarthatóság.

\section{Bevezetés}

A víz a fenntartható fejlődésünket komolyan befolyásoló tényezők egyike. Napjainkban azonban már több mint egymilliárd ember nem jut hozzá az elégséges édesvízmennyiséghez. Az egyik lehetséges módszer a víztakarékosságra az, ha a háztartásokban különféle, ivóvízminőséget nem igénylő tevékenységekre például WC-öblítésre, autómosásra vagy öntözésre úgynevezett kezelt szürkevizet használunk. Szürkevizeknek nevezzük a mosogatásból, fürdésből és mosásból származó használt vízfrakciókat, melyek nem érint- 
keznek a WC-öblítése során keletkezett vízzel. A kutatásunkban kiemelten vizsgált, mosásból származó frakció nagy koncentrációban tartalmaz mosószerekből származó detergenseket, vegyszereket, fehérítőt, ruhafestékanyagokat, olajat és nem lebomló szöveteket pl. a ruhákból [1].

A mosási folyamatok során a szennyeződések eltávolítására ún. felületaktív anyagokat, detergenseket használunk így a szürkevizekben nagy mennyiségű ilyen anyag található, amelyek a háztartási szennyvízzel kikerülhetnek a felszíni vizekbe. Itt a víz felszínén vékony habréteget képezve csökken a víz által felvehető oxigén menynyisége, illetve az öntisztulási folyamat hatásfoka, beindulhat az algavirágzás. Ezért újrahasználat előtt a szürkevizeket fontos ezektől a felületaktív anyagoktól és egyéb szennyezőktől is megtisztítani. Jelenleg még Magyarországon a szürkevíz felhasználásának nincs közegészségügyi szempontú kidolgozott szabályozása.

Az Egyesült Államokban azonban pl. az EPA (Environmental Protection Agency) 2012-ben kiadott egy útmutatót a szürkevizek újrahasználatára vonatkozóan. A minősítési paraméterek közül ebből a szabályozásból két paramétert emelek ki: a biológiai oxigényigény (BOI5) értékét, amelyet 10 mg/l koncentrációban, illetve a zavarosságot, melyet 2 NTU értékben javasolják maximalizálni az újrahasználat feltételeként [2]. Így ezen paraméterekre kiemelt figyelmet fordítottunk a kezelési eljárások kidolgozása során.

\section{Szintetikus szürkevíz}

A szürkevízkezelési műveletek tisztítási hatásfokának összehasonlítása érdekében egy állandó összetételü, ivóvízalapú mosóvizet állítottunk elő, amely minőségi szempontból jól reprezentálja a valós, mosásból származó szürkevízfrakciót. A valós minták összetétele nagyon változó, így a korrekt kezelési hatásfokok nyomon követésére szükséges a kezelendő víz összetételének állandósága, mely szintetikusan, adott receptúra alapján kidolgozható, és később biztosítható a vizsgálatokhoz. A szintetikus mosóvíz előállításakor az elérendő minőségi paraméterek iránymutatójául a Környezetmérnöki Tanszék korábbi kutatásai alkalmával meghatározott minőségi összetétel szolgált [3, 4]. A minták alkotó komponensei mosószer és öblítő, valamint a szennyeződések reprezentálása érdekében növényi olaj és természetes eredetű szerves tápanyag voltak.

Vizsgáltuk továbbá a kezelés hatását az egyre népszerűbb ún. biodetergenst tartalmazó mosószerekre is. A „bio”-mosóvizek mintázása során hagyományos mosószer és öblítő helyett folyékony mosódiót, valamint növényi és ásványi anyagokból előállított öblítőt használtunk. Minősítési lépésként párhuzamos mérésekben vizsgáltuk a minták pH-, zavarosság-, fajlagoselektromosvezetőképesség-, zéta-potenciál-, biológiai oxigénigény-, oldottszervesszéntartalom- és kémiaioxigénigény-értékeit.

\subsection{ANA-detergenstartalom-meghatározás}

A fentiekben bemutatott vízanalitikai paraméterek folyamatos mérése mellett az egyes kezelési fázisok között, a kezelési lépés hatékonyságának ellenőrzése érdekében speciális összegző-paraméter mérését is elvégeztük. Ez az ún. anionaktív detergens (ANA)-tartalom. Mivel a valós és a szintetikus mosóvizekben megtalálható mosószerek elsősorban anionaktív detergenseket tartalmaznak, így érdemes meghatározni a kezeletlen mosóvíz-minta anionaktívdetergens-tartalmát, majd nyomon követni ezen összegző-paraméter alakulását a komplex kezelési folyamat során is

Az anionaktív detergens mennyiségi meghatározására szolgáló módszer egy kétfázisú titrálás, mely egy nagyon egyszerü és gyors meghatározási módszer, viszonylag kevés eszköz- és vegyszerszükséglettel. Az alkalmazott mérési módszer alapját az ISO 2271:1989 szabvány adta [5].

\section{Komplex kezelési eljárás}

A különböző szürkevízkezelési eljárások fokozatos alkalmazása során vizsgáltuk azok hatását a hagyományos és biomosószereket tartalmazó szürkevízmintákra, majd ezt követően a lépések optimális összeillesztésével egy komplex kezelési eljárást dolgoztunk ki. Ezen eljárás műveletei: koagulálás, szűrés, valamint oxidáció.

\subsection{Koaguláció}

A kémiai kezelési eljárások kapcsán első lépésként a koaguláció esetében megállapítottuk az alkalmazott vas(III)-klorid koagulálószer optimális mennyiségét mindkét típusú minta esetében. A koagulációs kísérletek során a koauglálószert különböző koncentrációban adagoltuk a szürkevízmintához, miközben folyamatosan mértük a víz pH-, zavarosság- és zéta-potenciál-értékeit. Ezen vízminőségi mutatók segítettek megállapítani az optimális vegyszermennyiséget. Az optimális dózis hagyományos mosóvíz esetében 46-60 mg $\mathrm{FeCl}_{3}$, míg az bioszintetikus minta esetében ez a mennyiség 33,78-34,78 $\mathrm{mg} \mathrm{FeCl}_{3}$-hatóanyag volt $100 \mathrm{ml}$ mintára vonatkoztatva. Ezekből az érté- 
kekből jól látható, hogy biodetergensek használatával akár 42\%-kal kevesebb vegyszer használata elegendő lehet az optimális kezeléshez.

Az optimális dózissal kezelt minták jellemző paramétereit az 1. táblázat illusztrálja.

A megfelelő dózisú vegyszer adagolása mellett a szennyeződések pelyhek formájában kiülepednek a koagulálószerrel, így megkönnyítve a következő kezelési lépést, a szűrést.

\subsection{Kvarchomokon történő szürés}

A koagulálást követően a szűrési lépés során kvarchomok szűrőközegen szűrtük a mintákat (1. ábra), mely a koagulálószerrel pelyhekben összeállt szennyeződéseket nagy hatékonysággal eltávolította (2. ábra), ezzel csökkentve a minta zavarosságát és szervesanyag-tartalmát is.

Azonban a nemzetközi szakirodalomban ajánlott minősítési paraméterek felső határát - mely zavarosság esetében 2 NTU, míg a biológiai oxigénigény esetében $10 \mathrm{mg} / \mathrm{l}$ - még nem sikerült ekkor elérnünk. Ez látható a 2. táblázatban megadott értékek alapján.

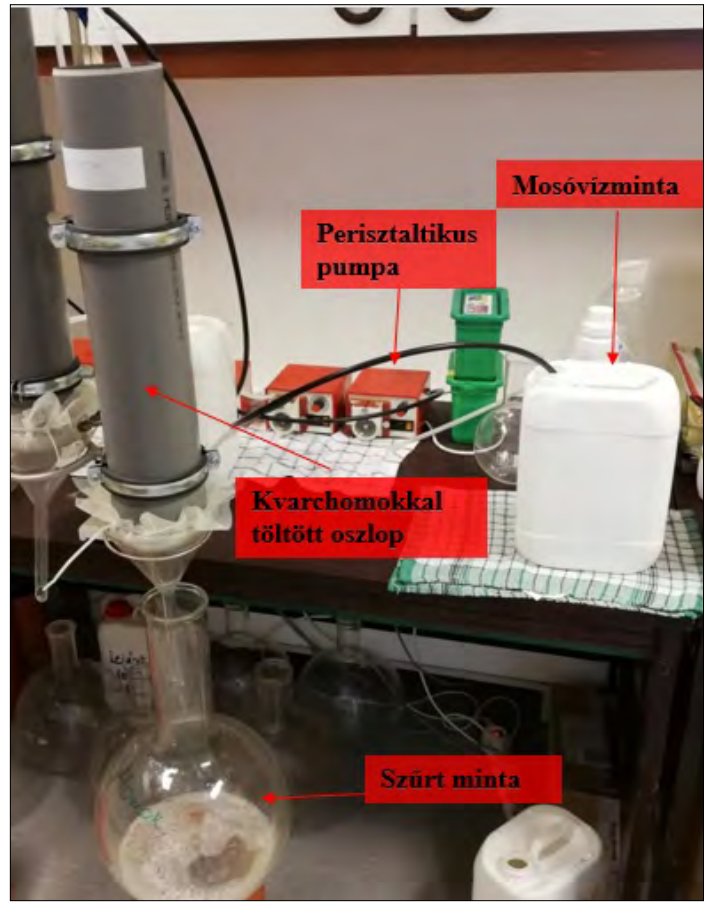

1. ábra. Kvarchomok szüröberendezés felépítése

1. táblázat. Optimális $\mathrm{FeCl}_{3}$-dózissal történő koagulálás hatása a mosóvízmintákra

\begin{tabular}{|l|c|c|c|c|}
\hline Mosóvízminták & $\begin{array}{c}\text { Hagyományos mo- } \\
\text { sószereket tartal- } \\
\text { mazó nyers minta }\end{array}$ & $\begin{array}{c}\text { Koagulált hagyomá- } \\
\text { nyos mosószereket } \\
\text { tartalmazó minta }\end{array}$ & $\begin{array}{c}\text { Biomosószereket } \\
\text { tartalmazó nyers } \\
\text { minta }\end{array}$ & $\begin{array}{c}\text { Koagulált biomosó- } \\
\text { szereket tartalmazó } \\
\text { minta }\end{array}$ \\
\hline pH & $7,783 \pm 0,170$ & $2,387 \pm 0,39$ & $7,82 \pm 0,15$ & $4,2 \pm 0,31$ \\
\hline $\begin{array}{l}\text { Fajlagos elektromos ve- } \\
\text { zetőképesség [mS/cm] }\end{array}$ & $1,03 \pm 0,021$ & $5,80 \pm 2,49$ & $1,64 \pm 0,08$ & $1,72 \pm 0,45$ \\
\hline Zéta-potenciál [mV] & $-33,93 \pm 0,351$ & $-2,47 \pm 0,77$ & $-37,88 \pm 2,11$ & $-3,08 \pm 5,25$ \\
\hline Zavarosság [NTU] & $85,17 \pm 8,819$ & $395,61 \pm 137,24$ & $40,69 \pm 5,59$ & $443,17 \pm 60,71$ \\
\hline BOI [mg/l] & $420 \pm 52,915$ & $76,67 \pm 2,88$ & $281,28 \pm 56,05$ & $65 \pm 13,23$ \\
\hline DOC [mg/l] & $255,19 \pm 20,73$ & $217,58 \pm 23,17$ & $149,06 \pm 40,03$ & $79,06 \pm 3,60$ \\
\hline
\end{tabular}

2. táblázat. Szürés hatása a koagulálószerrel kezelt mintákra

\begin{tabular}{|l|c|c|c|c|}
\hline Mosóvízminták & $\begin{array}{c}\text { Koagulált, hagyo- } \\
\text { mányos mosósze- } \\
\text { reket tartalmazó } \\
\text { minta }\end{array}$ & $\begin{array}{c}\text { Szürt, hagyományos } \\
\text { mosószereket tar- } \\
\text { talmazó minta }\end{array}$ & $\begin{array}{c}\text { Koagulált, biomosó- } \\
\text { szereket tartalmazó } \\
\text { minta }\end{array}$ & $\begin{array}{c}\text { Szürt, biomosósze- } \\
\text { reket tartalmazó } \\
\text { minta }\end{array}$ \\
\hline pH & $2,387 \pm 0,39$ & $7,624 \pm 0,208$ & $4,2 \pm 0,31$ & $7,07 \pm 0,51$ \\
\hline $\begin{array}{l}\text { Fajlagos elektromos ve- } \\
\text { zetőképesség [mS/cm] }\end{array}$ & $5,80 \pm 2,49$ & $1,94 \pm 0,12$ & $1,72 \pm 0,45$ & $1,41 \pm 0,38$ \\
\hline Zéta-potenciál [mV] & $-2,47 \pm 0,77$ & $10,23 \pm 3,68$ & $-3,08 \pm 5,25$ & $-7,88 \pm 6,97$ \\
\hline Zavarosság [NTU] & $395,61 \pm 137,24$ & $2,08 \pm 0,35$ & $443,17 \pm 60,71$ & $1,06 \pm 0,36$ \\
\hline BOI [mg/l] & $76,67 \pm 2,88$ & $22 \pm 14,73$ & $65 \pm 13,23$ & $14 \pm 2,59$ \\
\hline DoC [mg/l] & $217,58 \pm 23,17$ & $35,34 \pm 9,39$ & $79,06 \pm 3,60$ & $28,49 \pm 10,07$ \\
\hline
\end{tabular}




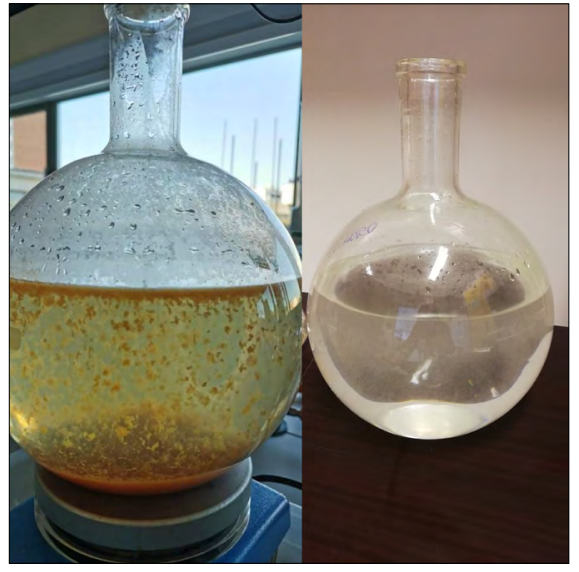

2. ábra. Szürés előtti (koagulált) és szûrés utáni minta

\subsection{Oxidatív kezelés}

Ezen lépés során optimálás alapján 128 mM hidrogén-peroxiddal kezeltük a már koagulált, majd szűrt mintát, majd 1 óra hatóidő után elemeztük az így oxidált minta minőségi jellemzőit. A kapott eredmények alapján az oxidatív kezelés végére a nemzetközi ajánlásoknak megfelelően a zavarosság kapcsán a 2 NTU alatti, valamint a biológiai oxigénigény tekintetében a $10 \mathrm{mg} / \mathrm{l}$ alatti értékeket kaptunk. Az oxidáció hatása látható a 3. táblázatban megadott értékek alapján.

\section{Komplex kezelési eljárás hatásfoká- nak összefoglalása}

Az alkalmazott kezelési lépések (koaguláláshomokszűrés-oxidálás) során megtisztított szintetikus mosóvíz minősége egyértelműen javult vízminősítési paramétereit tekintve. A 3-4. ábrák szemléltetik a nemzetközi szakirodalomban is kiemelt biológiaioxigénigény- és zavarosság-pa-

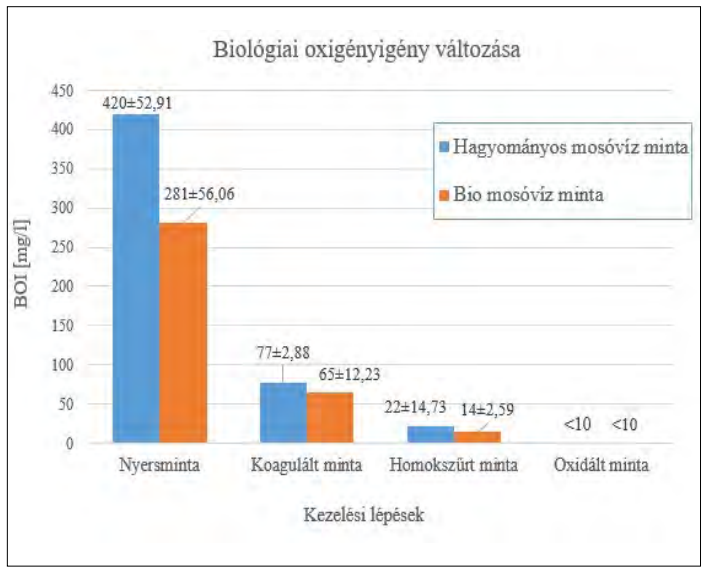

3. ábra. Biológiai oxigénigény csökkenése a komplex kezelési módszer lépései során

raméterek folyamatos csökkenését az egyes kezelési lépések során. A biológiai oxigénigény egyértelmű csökkenést mutat, azaz a komplex kezelés eredményeképpen elértük a $10 \mathrm{mg} / \mathrm{l}$ alatti értéket a nemzetközi minősítési ajánlásoknak megfelelően.

A zavarosság esetében a koagulálási lépés során a zavarosság jelentős növekedése figyelhető meg, ami a pehelyképződésnek köszönhető, ez azonban az azt követő szürési lépés követően lényegesen csökken, így a komplex kezelési módszer végére az ajánlott 2 NTU alatti értéket kaptunk.

Az ANA-detergens tartalom mérése kapcsán továbbá az eredmények alapján elmondható, hogy a komplex kezelési eljárás eredményesen eltávolítja ezen komponenseket a szürkevízből. Ahogyan az 5. ábrán is látható, a szűrési lépést követően az ANA-detergens-tartalom méréshatár alatti.

3. táblázat. Az oxidációs kezelési lépés hatékonysága

\begin{tabular}{|l|c|c|c|c|}
\hline Mosóvízminták & $\begin{array}{c}\text { Szűrt, hagyományos } \\
\text { mosószereket tar- } \\
\text { talmazó minta }\end{array}$ & $\begin{array}{c}\text { Oxidált, hagyomá- } \\
\text { nyos mosószereket } \\
\text { tartalmazó minta }\end{array}$ & $\begin{array}{c}\text { Szürt, biodetergen- } \\
\text { seket tartalmazó } \\
\text { minta }\end{array}$ & $\begin{array}{c}\text { Oxidált, biodeter- } \\
\text { genseket tartalmazó } \\
\text { minta }\end{array}$ \\
\hline pH & $7,62 \pm 0,208$ & $7,73 \pm 0,13$ & $7,07 \pm 0,51$ & $7,07 \pm 0,44$ \\
\hline $\begin{array}{l}\text { Fajlagos elektromos ve- } \\
\text { zetőképesség [mS/cm] }\end{array}$ & $1,94 \pm 0,12$ & $2,14 \pm 0,61$ & $1,41 \pm 0,38$ & $1,07 \pm 0,14$ \\
\hline Zéta-potenciál [mV] & $10,23 \pm 3,68$ & $17,23 \pm 0,11$ & $-7,88 \pm 6,97$ & $-14,4 \pm 4,77$ \\
\hline Zavarosság [NTU] & $2,08 \pm 0,35$ & $1,8 \pm 0,6$ & $1,06 \pm 0,36$ & $1,21 \pm 0,456$ \\
\hline BOI ${ }_{5}$ [mg/l] & $22 \pm 14,73$ & $<10$ & $14 \pm 2,59$ & $<10$ \\
\hline DOC [mg/l] & $35,34 \pm 9,39$ & $21,08 \pm 2,36$ & $28,49 \pm 10,07$ & $26,11 \pm 11,03$ \\
\hline
\end{tabular}




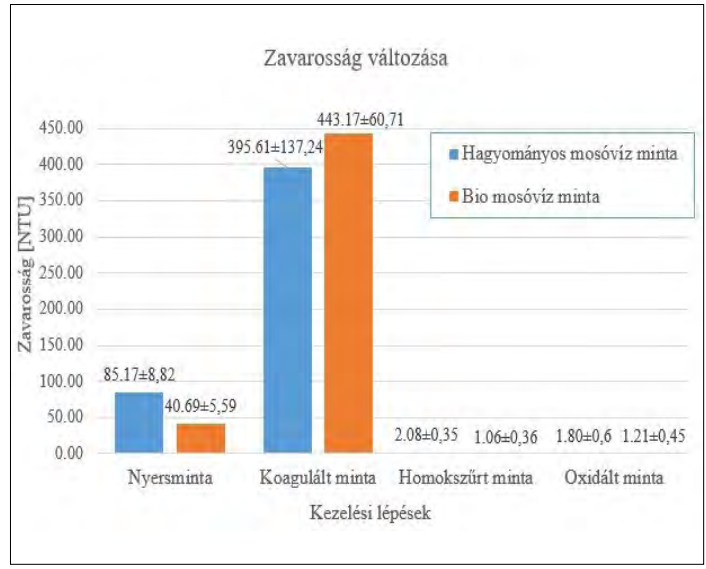

4. ábra. Zavarosság változása a komplex kezelési módszer lépései során

\section{Csíranövényteszt}

Az öntözési célra való újrahasználhatóság vizsgálatának céljából szabványosítottcsíranövény-tesztet végeztünk el [6]. A csíranövényteszt során fehér mustármagokat csíráztattunk 72 órán keresztül.

A kísérlet során 25-25 db kezeletlen, azonos méretű és színű fehér mustármagot helyeztünk egymástól egyenlő távolságban előzetesen sterilizált és szűrőpapírral bélelt Petri-csészékbe. A teszt időtartama 72 óra volt, mely során $20-22{ }^{\circ} \mathrm{C}-\mathrm{os}$ sötét helyiségben, csíráztatóládában tartottuk a magokat tartalmazó Petri-csészéket.

Három párhuzamos mérést végeztünk egy-egy alkalommal, úgy, hogy 3-3 Petri-csészét öntöztünk kontrollként ivóvízzel, kezeletlen szintetikus mosóvízzel illetve komplexen kezelt, tisztított szintetikus mosóvízzel. A kísérletet elvégeztük hagyományos, valamint biodetergenseket tartalmazó mosóvízzel is.

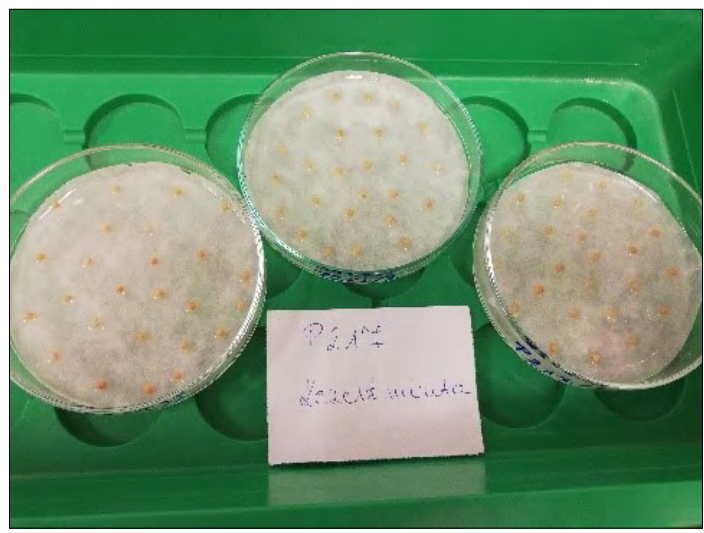

6. ábra. Fehér mustármagok

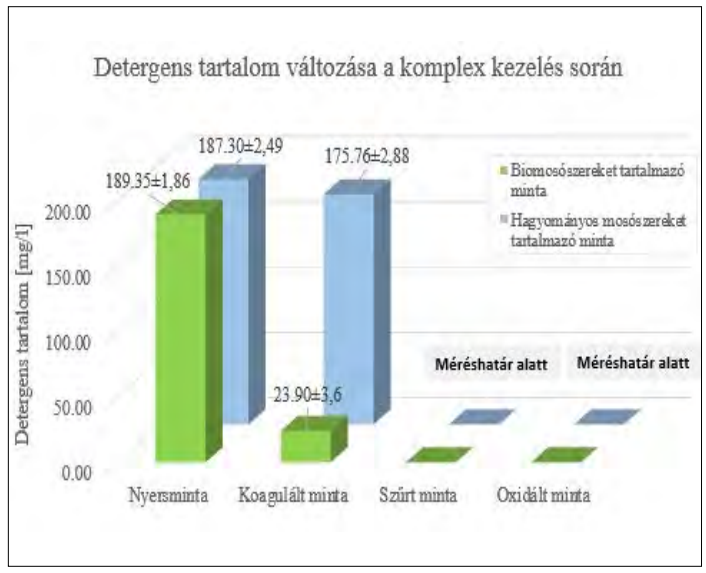

5. ábra. ANA-tartalom-változás a kezelés hatására

A 6-7. ábrákon látható a csíranövényteszt kiindulási állapota a fehér mustármagok, valamint a végső fázis, a fejlett csíranövények.

Vizsgáltuk az ivóvízzel öntözött magokhoz viszonyítva:

- hogy hány darab mag csírázott ki;

- milyen mértékű volt a növekedés (gyökér- és szárhossz tekintetében);

- a biomasszatömeget;

- az elemtartalmat.

A minősítés során elsőként megszámoltuk, hogy Petri-csészénként a 25 db csírából hány db mag csírázott ki. A gyökér és szárhossz mérését egyesével végeztük el minden kicsírázott növény esetén, a 72 óra leteltével. A kapott adatok felhasználásával összehasonlítást végeztünk az öntözővizek minőségi mutatói között. A nedves és száraz biomasszatömeget Petri-csészénként mértük le. A két adat felhasználásával nedvességtartalmat számoltunk a különböző vízmintákhoz tartozó

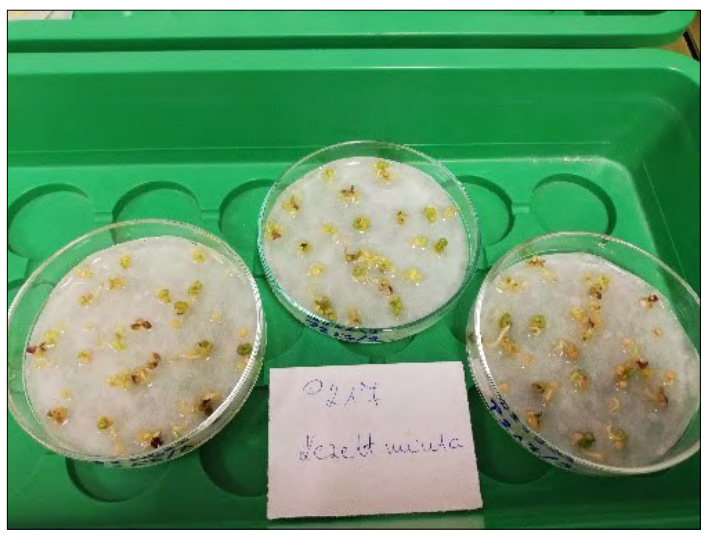

7. ábra. Csíranövények 
csíranövényekre, amely nagyon jó alapot jelentett az öntözővizek közötti különbségek összehasonlítására. Az elemtartalom-vizsgálat esetén külön elemeztük a szár- és a gyökérrészt.

\subsection{Kicsírázott magok száma}

Ahogyan a 4. táblázatban is látható, a kezeletlen mosóvízzel öntözött magok esetében kisebb a csírázási képesség, mint a kontrollivóvíz vagy a kezelt mosóvíz esetében. A kezelt minták mind a hagyományos, mind a biomosóvíz esetében jobb csíráztatóképességet mutatnak.

\subsection{Gyökér- és szárhossz}

A csírák növekedését a gyökér és a szárhossz mérésével követtük nyomon. A viszonyítási alapot ebben a kontrollivóvízzel öntözött magvak méretei jelentették. A milliméterben mért értékekből átlagot vontunk, ez látható a 5. táblázatban.

A vártnak megfelelően az tapasztaltuk, hogy a kezelt mosóvízzel öntözött csírák esetében nagyobb a szár- és gyökérhossz, mint a kezeltlen mintával öntözöttek esetében. Az ivóvízhez viszonyítva azonban látható lemaradás a növekedést illetően, a kezelt mintákkal való öntözés során is. Gyökérhossz esetében hagyományos mosóvízzel öntözött csírák esetében 60\%-kal kisebb, míg biomosóvízzel öntözött csíráknál ez az eltérés 55\%.

\section{4. táblázat. Átlagosan kicsírázott magok száma}

\begin{tabular}{|l|c|c|}
\hline & Átlag & Szórás \\
\hline Ivóvíz & 23,33 & 0,58 \\
\hline $\begin{array}{l}\text { Kezeletlen mo- } \\
\text { sóvíz }\end{array}$ & 19,00 & 1,00 \\
\hline Kezelt mosóvíz & 22,33 & 2,51 \\
\hline $\begin{array}{l}\text { Kezeletlen bio- } \\
\text { mosóvíz }\end{array}$ & 22,00 & 2,00 \\
\hline $\begin{array}{l}\text { Kezelt biomo- } \\
\text { sóvíz }\end{array}$ & 23,67 & 1,53 \\
\hline
\end{tabular}

5. táblázat. Gyökér- és szárhosszátlag

\begin{tabular}{|c|c|c|}
\hline GYÖKÉR (mm) & $\begin{array}{c}\text { Hagyományos } \\
\text { mosóvíz }\end{array}$ & Biomosóvíz \\
\hline Ivóvíz & $11,26 \pm 1,33$ & $15,84 \pm 2,03$ \\
\hline Kezeletlen & $3,85 \pm 1,09$ & $6,37 \pm 0,29$ \\
\hline Kezelt & $4,38 \pm 2,19$ & $7,24 \pm 0,62$ \\
\hline SZÁR (mm) & & \\
\hline Ivóvíz & $14,62 \pm 4,62$ & $11,35 \pm 1,17$ \\
\hline Kezeletlen & $7,65 \pm 0,09$ & $10,25 \pm 0,43$ \\
\hline Kezelt & $8,82 \pm 0,34$ & $11,15 \pm 0,99$ \\
\hline
\end{tabular}

Szárhossz esetében kisebb eltérést tapasztaltunk a kontrollivóvízzel öntözött csíráktól, hagyományos mosóvízzel öntözés esetében $40 \%$, biomosóvíz esetén $2 \%$ a lemaradás a növekedésben.

\subsection{Biomasszatömeg és nedvességtartalom}

A biomasszatömeg mérését nedves és száraz állapotban is elvégeztük. Ezen adatokból a növényicsíra-részek nedvességtartalmát határoztuk meg, amelyből a minták vízfelvevő képességére tudtunk következtetni.

Szinte minden esetben elmondható, hogy a kontrollivóvízzel öntözött csírák értékeihez viszonyítva kisebb értékeket mértünk, de a kezelt vízzel öntözött csírák tömege és nedvességtartalma magasabb, mint a kezeletlen mosóvízmintával öntözött csíráké.

A vízfelvevő képességet az öntözővíz detergenstartalma és a zavarosság értéke lényegesen befolyásolja, mivel a növényi részekre való kirakódásuk megakadályozhatja a vízfelvételt. A csíráztatás során ez abban mutatkozott meg, hogy míg az ivóvízzel és a kezelt mintákkal öntözött csírák az összes öntözővizet felvették, addig a kezeletlen mosóvízzel öntözött csírák alatt rendszerint megmaradt az előző öntözésekből származó vízminta. A kezelt minta esetében azonban ezeket a zavaró hatásokat nagyrészben sikerült eltávolítani. Továbbá az adatokat értékelve megállapítottuk, hogy a nedvességtartalom a gyökér esetében 10\%kal nagyobb volt a szárak nedvességtartalmához képest. Következtetésképpen ebből azt vontuk le, hogy a növényi csírákban a nedvesség inkább a gyökérrészben raktározódhat el.

\subsection{Elemanalízis}

A csíráztatási kísérlet csíranövényeinek, valamint az öntözésükre használt vízminták elemanalitikai vizsgálatát Agilent 5110 ICP-OES-készülék használatával végeztük el. 12 makro-, ill. mikroelem mérését végeztük el a növényi mintákon és vízmintákon egyaránt.

Az elemanalízis kapcsán külön a szár- és a gyökérrész vonatkozásában vizsgáltuk a csíranövény elemtartalmát. A 8. ábra a szárrész mikroelem-tartalmát illusztrálja.

Látható, hogy a vas, mangán és cink magas koncentrációban található meg a mosóvízzel öntözött csíranövényben, azonban mivel ezek az elemek az ivóvízzel öntözött csíranövényben is hasonlóan magas koncentrációban vannak jelen, így ez nem jelent többletfelhalmozódást.

A kapott eredmények alapján összességében elmondható, hogy a mosóvíz kezelése elengedhetet- 


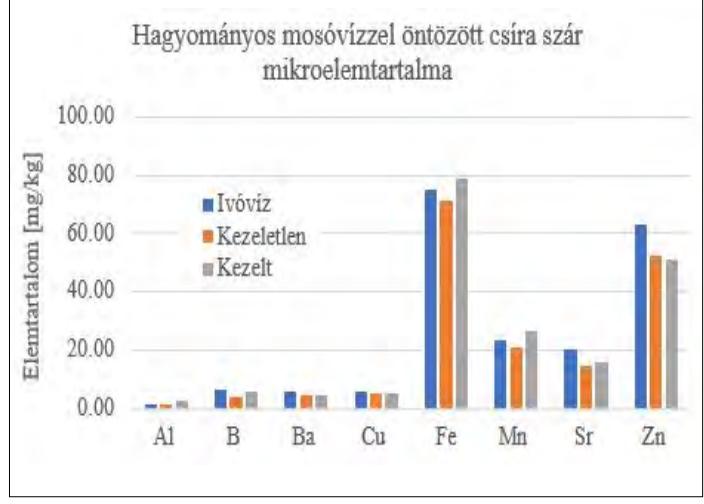

8. ábra. Csíraszár mikroelem-tartalma

len öntözési célú felhasználás előtt, hiszen a kezeletlen mintával öntözött magok, mind kicsírázási arányban, mind pedig fejlődésben elmaradtak a kezelt, illetve az ivóvízzel öntözött magokhoz viszonyítva.

\section{SAR-tényező}

A SAR-érték/-tényező egy szakirodalomban elérhető tapasztalati képlet alapján a vizek szikesítő hatását mutatja meg, pl. öntözővizek minőségére vonatkozóan. A szikesedését abból a szempontból fontos vizsgálni, hogy a talaj, illetve öntözővíz sótartalma meghatározza a talaj termőképességét. Abban az esetben, ha a minta SAR-értéke 2-4 közötti, az öntözővíz nem veszélyezteti a talaj termőképességét, míg ha ettől nagyobb, jelentős hatással lehet az öntözővíz minősége a talaj tulajdonságaira, a növények fejlődőképességére [7].

6. táblázat. Kezelés hatása a hagyományos mosóvízmintára

\begin{tabular}{|l|c|c|}
\hline & $\begin{array}{c}\text { Kezeletlen, } \\
\text { hagyományos } \\
\text { mosószereket } \\
\text { tartalmazó } \\
\text { minta }\end{array}$ & $\begin{array}{c}\text { Kezelt, ha- } \\
\text { gyományos } \\
\text { mosószereket } \\
\text { tartalmazó } \\
\text { minta }\end{array}$ \\
\hline pH & $7,783 \pm 0,170$ & $7,73 \pm 0,13$ \\
\hline $\begin{array}{l}\text { Fajlagos elektromos } \\
\text { vezetőképesség [mS/ } \\
\text { cm] }\end{array}$ & $1,03 \pm 0,021$ & $2,14 \pm 0,61$ \\
\hline Zéta-potenciál [mV] & $-33,93 \pm 0,351$ & $17,23 \pm 0,11$ \\
\hline Zavarosság [NTU] & $85,17 \pm 8,819$ & $1,8 \pm 0,6$ \\
\hline BOI ${ }_{5}$ [mg/l] & $420 \pm 52,915$ & $<10$ \\
\hline DOC [mg/l] & $255,19 \pm 20,73$ & $21,08 \pm 2,36$ \\
\hline KOI [mg/l] & $1258 \pm 33,94$ & $1258,5 \pm 26,16$ \\
\hline ANA-detergens [mg/l] & $187,07 \pm 3,49$ & $<$ \\
\hline
\end{tabular}

Ez az érték hagyományos mosóvíz esetében 2,38, míg biomosóvíz esetében 2. Ez azt jelenti, hogy ezen paraméter alapján az általunk komplexen kezelt mosóvíz alkalmas lehet öntözésre, anélkül, hogy károsítaná a talaj termőképességét.

\section{Következtetések}

A mosásból származó szürkevíz újrahasználatra való előkészítése során, mint kezelési eljárást, komplexen alkalmaztunk koagulációt, kvarchomok szűrőközegen történő szürést, valamint oxidációs eljárást. A mért és elemzett vízanalitikai paraméterek alapján sikeresen alkalmaztunk egy megfelelő kezelési metódust, optimális vegyszermennyiségek használatával. A kiindulási kezeletlen, valamint a komplexen kezelt minták paraméterei láthatóak a 6-7. táblázatokban.

Ennek eredményeképpen a minőségre vonatkozó nemzetközi ajánlásokban szereplő minősítési paraméterek közül kettőt kiemelve a biológiai oxigénigény (BOI5) értékét $10 \mathrm{mg} / \mathrm{l}$, illetve a zavarosságot 2 NTU érték alá sikerült redukálni. Így egy háztartási szinten, ivóvíz-minőségű vizet nem igénylő feladatokra potenciálisan (WC-öblítés, autómosás, öntözés) újrahasználható, mosásból származó tisztított szürkevizet állítottunk elő.

A csíranövényteszt elvégzése kapcsán továbbá megállapítható, hogy a komplexen kezelt mosóvíz potenciálisan alkalmas öntözési célú felhasználásra, valamint a SAR-tényező alapján nem gyakorol káros hatást sem a talaj termőképességére.

\section{7. táblázat. Kezelés hatása a biomosóvíz-mintára}

\begin{tabular}{|l|c|c|}
\hline & $\begin{array}{c}\text { Kezeletlen, } \\
\text { biomosósze- } \\
\text { reket tartal- } \\
\text { mazó minta }\end{array}$ & $\begin{array}{c}\text { Kezelt, bio- } \\
\text { mosószereket } \\
\text { tartalmazó } \\
\text { minta }\end{array}$ \\
\hline pH & $7,82 \pm 0,15$ & $7,07 \pm 0,44$ \\
\hline $\begin{array}{l}\text { Fajlagos elektromos } \\
\text { vezetőképesség [mS/ } \\
\text { cm] }\end{array}$ & $1,64 \pm 0,08$ & $1,07 \pm 0,14$ \\
\hline Zéta-potenciál [mV] & $-37,88 \pm 2,11$ & $-14,4 \pm 4,77$ \\
\hline Zavarosság [NTU] & $40,69 \pm 5,59$ & $1,21 \pm 0,456$ \\
\hline BOI [mg/l] & $281,28 \pm 56,05$ & $<10$ \\
\hline DOC [mg/l] & $149,06 \pm 40,03$ & $26,11 \pm 11,03$ \\
\hline KOI [mg/l] & $1341 \pm 28,99$ & $909 \pm 2,83$ \\
\hline ANA-detergens [mg/l] & $189,95 \pm 2,14$ & $<$ \\
\hline
\end{tabular}




\section{Szakirodalmi hivatkozások}

[1] Ghaitidak D. M., Yadav K. D.: Characteristics and Treatment of Greywater. A Review. Environmental Science and Pollution Research, 20/5. (2013) 2795-2809.

https://doi.org/10.1007/s11356-013-1533-0

[2] U.S. Environmental Protection Agency: Guidelines for Water Reuse. 2012.

[3] Bodnár I., Boros N., Baranyai E., Fórián S., Izbékiné Szabolcsik A., Jolánkái G., Keczánné Üveges A., Kocsis D.: Épületek csapadékvizeinek és szürkevizeinek vizsgálata az Észak-Alföld régióban környezetbarát és energiahatékony hasznosítás céljából. In: Kalmár F. (szerk.): Fenntartható energetika megújuló energiaforrások optimalizált integrálásával. Akadémiai Kiadó, Budapest, 2014.
[4] Bodnar I., Szabolcsik A., Baranyai E., Uveges A., Boros N.: Qualitative Characterization of the Household Greywater in Northern Great Plain Region of Hungary. Environmental Engineering and Management Journal, 13/11. (2014) 2717-2724. https://doi.org/10.30638/eemj.2014.302

[5] ISO 2271:1989: Surface Active Agents - Detergents - Determination of Anionic-Active Matter by Manual or Mechanical Direct Two-Phase Titration Procedure.

[6] MSZ 22902-4: Víztoxikológiai vizsgálatok. Csíranövényteszt. 1991.

[7] Zsembeli J., Szűcs L.: Zöldségnövények környezetkímélő öntözése magas sótartalmú vizekkel. Agrártudományi Közlemények, 2014/61. 